\title{
EDUCATIONAL POLICY : THE ART OF DECISION MAKING FOR ECONOMICS STUDENT INTERNSHIP PROGRAM
}

\author{
Karuniana Dianta Arfiando Sebayang ${ }^{1}$, Darma Rika Swaramarinda ${ }^{2}$ \\ Universitas Negeri Jakarta \\ Email : dr.dianta@gmail.com, darmarikas@gmail.com
}

\begin{abstract}
This study aims to evaluate the Internship Program which is required by Faculty of Economics and find out the extent of success of the Internship Program in order to develop human skills, and formulate policy recommendations to improve such activities in the future. This research uses descriptive deductive method and model evaluation of the Context-Input-Process-Product ( CIPP) program. From the research result, it is found that implementation in context, input, process and product aspects has been done with various results. There are 6 issues of strategic issues raised based on interviews that are considered to be considered in regard to the internship program. Researchers also give 6 policy recommendations to be implemented by the faculty that will impact on the human development of the world of education in general.
\end{abstract}

Keywords: CIPP Program Evaluation, Policy, Economics Student, Internship Program.

\section{INTRODUCTION}

The University and faculties provide an opportunity for students to obtain a more comprehensive picture of the world of work and apply theories and practices in the field by requiring students to undergo an internship program tailored to the needs of each course (Chen et al., 2018; Kelly et al., 2017). The internship program gives students the competence to be more familiar with, knowing, and practicing to analyze the working environment (Kelly et al., 2017; Khalil, 2015). This is as an effort to prepare students in entering the world of work (Dombrowski et al., 2013). Implementation of this internship program is made by Diploma students at least 2 (two) months and Bachelor's students at least 1 (one) month, even now Diploma program has launched internship program in company for 6 (six) months intensively. Internship program as compulsory subject. The internship is possible to be extended in accordance with the agreement between the student and the apprentices so far not to interfere with academic activities. Therefore, internship are held during long semester breaks. The current internship program targets that students should be placed in work units as well as assignments or jobs that are appropriate to the field of study or competence (Hamidah et al., 2012; Lam and Ching, 2007). So far the implementation of the internship program only provides guidance in force, guidance on the study program, then supervisors assist in making an internship report which will be presented later.

Among universities, public policy into a special assessment in research and writing so that today many experts write and publish books that discuss the theories 
of public policy with an emphasis different, because each expert review them based on rumors, symptoms and problems that develop in the community. Gambhir Bhatta in Nugroho (2009) governance is the relationship between government and citizens that enable public policies and programs to be formulated, implemented and evaluation. Then Peterson (2003) says that what is meant by "public policy is governmentaction to address some problem ". Lester and Steward (2000) explain public policy is a process or a series or pattern of governmental activities or decisions that are design to remedy some public problems, either real or imagined. Arikunto (2012) said that, Program evaluation is a unit or unit of activity aimed at collecting information about realization or implementation of a policy, takes place in a continuous process, and occurs within an organization involving a group of people for decision-making. So it can be concluded that the evaluation program is a series of activities conducted deliberately and carefully to determine the level of implementation or success of a program by knowing the effectiveness of each component, both on the program being run as well as programs that have been passed.

Setiawan (1999) the main dimensions of evaluation are directed to the outcomes, benefits, and impacts of the program. In principle, an evaluation tool that can be measured through four dimensions is the input, process, output, and outcomes. There are many models of program evaluation used by experts. One is the CIPP model (Context-Input-Process-Product ). This model was developed by Stufflebeam (2014), CIPP model looks at four dimensions: Context dimension, Input dimension, Process dimension and Product dimension". The uniqueness of this model is on any type of evaluation related to the decision making device concerning the planning and operation of a program. The advantages of the CIPP model provide a comprehensive evaluation format at each stage of the evaluation ie the context, input, process and product stages.

This article would like to explore the evaluation and input given from the stakeholders for the university and faculty to see the need to prepare students in the internship program, considering the internship program is a mandatory program that must be taken by the students as a condition of obtaining bachelor and diploma degree. Opposite if students do this with voluntary needs, according to Szafran (2007), describes a straightforward approach to assessing the effect of an educational program when individual student participation in the program is voluntary, pretests are not feasible, and the statistical expertise of program personnel or assessment audiences is limited. Background characteristics of students believed to influence the outcome of interest are selected. But we still need the evaluation program in order to improve the program. Similarly with Gajda (2004), uneasy thoughts are often lurking somewhere in the back of their minds-we need to evaluate this program, but how the heck are we going to do that? Program evaluation can seem daunting (and maybe even a waste of precious time, energy, and other resources). And yet, inevitably, evaluation questions start surfacing: How are things going? Are we making a difference? Are the participants benefiting? How can we demonstrate that this program should be re-funded?.

Based on these things, in this article, researcher need to see how far this internship program is effective in various stages of either of context, input, process and product. 
Table 1 Evaluation Criteria

\begin{tabular}{|c|c|c|c|c|}
\hline No & $\begin{array}{c}\text { Components } \\
\text { Evaluated }\end{array}$ & $\begin{array}{c}\text { Aspects that are } \\
\text { evaluated }\end{array}$ & Evaluation Criteria & $\begin{array}{c}\text { Evaluation } \\
\text { Stage }\end{array}$ \\
\hline 1. & Program Preparation & $\begin{array}{l}\text { Aim, } \\
\text { Benefits } \\
\text { General } \\
\text { requirements }\end{array}$ & $\begin{array}{ll}\text { Achieved: Aim and } \\
\text { Benefits } \\
\text { Conformity: General } \\
\text { requirements }\end{array}$ & Context \\
\hline 2. & $\begin{array}{l}\text { Program } \\
\text { Requirements }\end{array}$ & $\begin{array}{l}\text { Entry requirements } \\
\text { Supervisor }\end{array}$ & $\begin{array}{l}\text { Fulfillment of criteria: } \\
\text { Entry requirements } \\
\text { Supervisor }\end{array}$ & Input \\
\hline 3. & $\begin{array}{l}\text { Program } \\
\text { Implementation }\end{array}$ & $\begin{array}{l}\text { Activity during } \\
\text { internship, } \\
\text { Student duties } \\
\text { during internship } \\
\text { Evaluation and } \\
\text { assessment. }\end{array}$ & $\begin{array}{l}\text { Walking and fulfillment: } \\
\text { Activity during internship } \\
\text { Student duties } \\
\text { during internship } \\
\text { Evaluation and } \\
\text { assessment. }\end{array}$ & Process \\
\hline 4. & Program Results & $\begin{array}{l}\text { Competencies } \\
\text { apprentices }\end{array}$ & $\begin{array}{l}\text { Achieving competence of } \\
\text { apprentices }\end{array}$ & Product \\
\hline
\end{tabular}

\section{METHODS}

This research uses qualitative deductive method or approach, because the purpose is to describe about a certain variable, symptom, condition or social phenomenon. This model divides the evaluation into four dimensions: (a) Context evaluation provides information in planning a program, how to rationalize the program and diagnose a needs that should be available; (b) Input evaluation includes analysis relating to how the use of available resources and alternative strategies should be considered for achieving a program; (c) Evaluation of the process is an evaluation designed and applied in the practice of program emplementation, including identifying procedural problems, the management of events and activities; (d) Product evaluation is a collection of descriptions and judgment outcomes in relation to context, input and process; or evaluation measures the success of goal achievement

Table 2 Evaluation Planning

\begin{tabular}{lllcl}
\hline \multicolumn{1}{c}{$\begin{array}{c}\text { Aspects / } \\
\text { Indicators }\end{array}$} & Data source & \multicolumn{1}{c}{ Technique } & $\begin{array}{c}\text { Stage } \\
\text { Evaluation }\end{array}$ & $\begin{array}{l}\mathrm{R} \\
\text { E }\end{array}$ \\
\hline Aim, & Guide book & Document Analysis & Context & C \\
Benefits & Key Informant & Interview & \\
$\begin{array}{l}\text { General } \\
\text { requirements }\end{array}$ & & Questionnaire & & O \\
Entry requirements & Guide book & Document Analysis & Input & M \\
Supervisor & Key Informant & Interview & & L \\
& & Questionnaire & & $\mathrm{M}$ \\
\hline
\end{tabular}




\begin{tabular}{lllll}
\hline Activity during & Guide book & Document Analysis & Process & I \\
internship & Key Informant & Interview \\
Student duties & & Questionnaire & E \\
during internship & & & $\mathrm{C}$ \\
Evaluation and & & & $\mathrm{N}$ \\
assessment. & & & $\mathrm{Y}$ \\
& & & $\mathrm{D}$ \\
Competencies of & Guide book & Document Analysis & Product & $\mathrm{T}$ \\
apprentices & Key Informant & Interview & I \\
& & Questionnaire & & O \\
& & & $\mathrm{N}$ \\
\hline
\end{tabular}

Table 3 Evaluation Guide Evaluationn

\begin{tabular}{cll}
\hline Scoring scale & \multicolumn{1}{c}{ Rating } & \multicolumn{1}{c}{ Evaluation Notes } \\
\hline 1 & Low & $\begin{array}{l}\text { The evaluation criteria are not fulfilled } \\
\text { completely or partially fulfilled, under } \\
\text { fifty percent of the number of criteria. }\end{array}$ \\
\hline 2 & Moderate & $\begin{array}{l}\text { Evaluation criteria are partially met, fifty } \\
\text { percent or more of the number of criteria. }\end{array}$ \\
\hline 3 & High & Evaluation criteria are met all. \\
\hline
\end{tabular}

\section{RESULTS AND DISCUSSION \\ Evaluation Context Internship Program}

Some things that can be evaluated from the context of this internship Program, that is Based on the results of questionnaires and interviews with key informants and other related parties, $82 \%$ of respondents considered the objectives of the internship program has been met well. While the remaining $18 \%$ is still not fulfilled well with the reasons of which there are still students who work not in accordance with the field, internship is still not optimal because it does not go through the process of guidance and lecturer involvement process.

In terms of the benefits of internship programs, view from various sides namely benefits to companies, students, faculty and university. Based on interviews with key informants, $88 \%$ see that the benefits of internship program is good, with the reason to establish corporate cooperation, in addition students can apply the skills, skills and professional attitude in the company. While the remaining $12 \%$ see that the benefits have not been achieved well, with the reason institutionally achieved ( networking ), but the acceptance of students as workers in private does not add other skills .

In the case of general provisions, b erdasarkan interviews with key informants, $85 \%$ see that the general provisions of the program has been good, the grounds are in accordance with the existing guidelines. While the remaining $15 \%$ see that the general provisions have not been good, with reasons need improvement according to conditions, not all general requirements of internship program inaccordance with the implementation, but in general are in accordance with the provisions. 
Indicators of Success Context Phase Internship Program

If you look at some of the evaluations in the context of the internship program above, it can be concluded that the implementation of the program context is high.

\section{Evaluation of Input Internship Program}

Some of the things that can be evaluated from this internship program input are: In terms of the requirements of internship program participants, based on the results of interviews and questionnaires obtained then $97 \%$ assessed that the basic skills and skills of participating students to follow the program is appropriate, and the remaining 3\% are still not appropriate.

In terms of lecturer criteria, based on the results of interviews and questionnaires obtained then $74 \%$ of respondents considered that the lecturers have been good and fulfilled because the supervisor already has the competence to only observe the company, thus supporting the internship activities . But there are still $26 . \%$ who judge that some of the supervisors on the program are still busy andless than optimal in guiding.

Indicators of Success Phase Input Internship Program

If you look at some of the evation on the input of the internship program above, it can be concluded that from the terms of the participants and lecturers there are results high.

\section{Evaluation of Process of Internship Program}

Some things that can be evaluated from the process of this internship Program, namely: In terms of student activity during internship program, based on interviews and questionnaires obtained then $76 \%$ rate that student activity during internship has been good so far, with the reason seen from the appraisal of the apprentice states that the apprentices have good, both the value of work and absenteeism, the assessment of the average company scored above 80 . While the remaining 24\% stated that the student activity during the internship is still not in accordance with the reason of competence and the field of student work is still there that is equated with the students of the school, not necessarily according to the field of study (currently doing administrative work in public companies), and they have obligations like employees .

So Similarly, in terms of students for internship assignments, interviews and questionnaires obtained the $71 \%$ assessed that the work of students during internships have good reasons and the value of a good company because it was assisted by student interns. If placed in accordance with the field or prodi then fulfilled and has the maximum, unless the field does not match. In addition, there has been direction from the company related tasks given so that students are able to carry out and complete the task well. The tasks given can work well and are fulfilled because students have high enthusiasm in internship. While 29\% considered that their task is still not optimal because the students are still running alone, sometimes there are companies that did not give assignments to students.

In terms of evaluation and assessment, based on the interviews and questionnaires obtained, 91\% considered that the evaluation and assessment were good because the average student received good or excellent grades, the company 
was willing to give value to the tasks during the internship and run objectively. Then, the evaluation and appraisal of apprenticeship students has been going well with the reports and internships, where there are 2 (two) parties who evaluate mentors and companies. However, there are still $9 \%$ who rated less well, because the current assessment is less true, as supervisors only judge based on reports and seminar argumentation, not based on field activities because there is no direct monitoring.

Indicators of Success Stage Process Internship Program

Indicators of success at this stage of the process of internship program look at these aspects, we conclude that there is a high.

\section{Product Evaluation of Internship Program}

$\begin{array}{ccc}\text { Some things that can be evaluated } & \text { from the } \\ \text { product internship program, namely } & \text { with }\end{array}$ student internship program that is already running, based on interviews and questionnaires obtained $79 \%$ considered that already tested the quality of apprentices because competence has been achieved either by exam, technically speaking students looks competent because there is no difficulty in internship. Another case with $21 \%$ of respondents rate that the competency has not been achieved optimally because there are still assessing the material in the less useful or applicable lectures in the field.

Product Success Indicator of Internship Program

The indicator of success at this stage of product of internship program look at these aspects it is concluded that the product stage is moderate. There are several strategic things that researchers can ask about it in terms of improvement, based on the results of interviews and questionnaire data are distributed. Requires cooperation from University and Faculty with stakeholders in accordance with student scholarship. Based on the interview result of the researcher with key informant, according to key informant $\mathrm{A}$, the head of the study program, he argues that it is necessary to collect data of cooperation between universities and stakeholders (minimum data base). Similarly, according to key informant B who is also one of the lecturers, he added that this program can run well provided that networking is built from the faculty (facilitated), the SOP should be clarified or restricted according to the field, eg accounting in what scope of work. Similarly, according to the key informant $\mathrm{C}$, head of the Faculty, that the need to increase cooperation through a written document or MoU. Agreed with that, according to the key informant $D$, as the leader of the study program, from the prodi should help students find companies that fit their scholarship, need a networking from prodi (preferably there is a link), although from students usually find their own. Another opinion by key informant $\mathrm{E}$ as the company that the need for a special person to handle the internship program and corporate cooperation with the Faculty or study program.

Also supported by students who become key informants , including F , G , H , I , J , K and L that the university and faculty should cooperate with the company so that students have a place to do internship program so that students are not confused to find their own apprentices, can give recommendation of places that can be used as an apprenticeship, so as not in vain in running an apprenticeship. Agreed with some of the above opinion, the researcher also 
assessed the need for cooperation and coordination from various parties that support the internship program activities, both from University, Faculty, Study Program, corporate partners and lecturers and participants of the Internship Program so that activities can be well coordinated.

Compatibility of competence with the field of work at the MODES. Based on the evaluation and indicators of success at each stage, what can be reviewed is the need for conformity of assignment at the internship with competence and study program. According to Key informant $M$, head of the faculty affairs, the need for placement of work field must be in accordance with the study program. Added by key informant $\mathrm{N}$, lecturer pembmbing, $\mathrm{s}$ angat pity so far there are still students who are apprentices in the assignment of the apprentices are still many who are not in accordance with the competence or prodinya, there are still placed in the administrative work is not a trading system. Similarly, according to the key informant B , SOPs should be clarified and restricted to areas, such as accounting in what scope of work. Supported also by key informant 0 from the company, it is necessary to mapping the field of internship work that is tailored to the pro gram stu in so as appropriate.

Supported also by students as resource persons, including key informant P and Q clicking expect for the internship program further students can work in accordance with the field and expertise in accordance with what he learned so that knowledge learned can be applied and for the internship program would be better if it focused suit with their respective fields. But according to the key informant $\mathrm{R}$ that the internship program is running well and the students perform internships according to their competence, and can establish relationships so that faculty graduates are easily accepted in the world of work. Agreeing with some opinions above, the researchers also assessed the need for conformity of assignment at the internship with competence and study program to be relevant to the courses obtained in the lecture bench.

Require the preparation of special competence for apprenticeship for students. Based on the interview result of the researcher with the key informant $M$, the head of the faculty affairs, who believes that the internship is good and should be continued, but it needs to be equipped with special competence for student. Agreed with him, the key informant 0 from the company also assessed that the maturity of only 1 (one) month needs to be added, the guidance needs to be maximized, there is at least a briefing of the study program before the activity is carried out.

Also supported by students include key informant $S$ that students should be given direction to perform internships in a good place like under the ministry for students to work in accordance with their fields and get a good experience. Added by key informant $\mathrm{T}$ that the training should be carried out internships and supervisors need to direct clearly about the apprenticeship report. Supported by key informants for better internship activities, an internship briefing program should be held to ensure that students have an overview before apprenticeship and a good workplace recommendation.

Agreeing with some of the above opinion, the researchers also assessed the need for the provision of the first facilitated by the faculty so that students can be better prepared in the internship . 
Requires detailed guidelines. According to key informant $\mathrm{C}$, head of the faculty, that the need for manual improvements, supported by the key informant $M$, has not been detailed in the apprenticeship report, so it needs to be improved in more detailed apprentices manual. It should be added to the handbook socialization roles and responsibilities of the supervisor according to key informants B. Agreeing with some of the above opinions, the researcher also assesses the need for improvements to existing apprentice manuals, adjusted to the latest developments taking place in the field.

Need to optimize guidance by supervisor. According to the key informant $\mathrm{M}$, faculty leaders need to increase the intensity of monitoring from supervisors, Similarly, according to the key informant $V$ the company states that the internshipguidance that has been done by lecturers need to be developed by doing direct guidance on the internship. Agreed with that, the key informant N, supervising lecturer that the lecturer's duties need to be clarified, whether for the purposes of guiding reports and seminars only, or need to take and pick up to the company where the practice for the good name of the institution. Added also by the key informant $S$ that the guidance by the supervisor should be optimized. Key informant key informant $\mathrm{C}$ also revealed that the supervisor should make a visit but return to the funding issue.

This is also supported by the students who have undergone an internship program including key informant $\mathrm{W}$ that supervisor lecturers should make a visit when students are implementing an apprenticeship program. In addition to the visit of lecturers to the place of practice, key informant X students also convey the need for a common perception of technical matters both mentoring material and preparation of apprenticeship report .

Agreed with some of the above opinion, the researcher also assessed the need for optimization of supervisor lecturers to be effective not only in the coaching of preparing the apprenticeship report but also monitor or down to the field, but until now it has not been regulated in internship guidelines or faculty rules .

Requires additional time for apprenticeship program. According to key informant $\mathrm{V}$, the company that gives the input that the time should be added for the apprenticeship program not only for 1 (one) month because the students need to add a lot of experience in the company as a stock later work. Agreeing with some of the above opinion, the researcher also considered the need to be discussed in advance whether it takes longer time for apprenticesconsidering the students also there are other activities, but until now it is only regulated about the addition of time at the university level that the internship program will held for 6 (six) months, but in the guidebook internship program has not been set on the matter.

\section{CONCLUTION}

Policy ecommendations : Sustainability Internship Program with some improvements Taking into account the 6 strategic issues in the Program mentioned earlier, we want to give numbers of policy recommendation to the internship Program activities : (1) That the internship program is good and can be continued because there is optimism in the running of the program with long-term impact on the development of professionalism and improvement of the quality or the quality of the student graduates for example with the addition of internship time; (2) It needs to do 
cooperation program or partnership with company, so that better prepared and coordinated well so that student not many who seek their own problems of irrespective of work field with background which pursued; (3) Need a special team that handles partnership issues with the company, considering the coming years the number of internship program participants will also increase; (4) It needs to be improved in the manual especially regarding the duties of supervisors to make the internship program more effective; (5) For all universities, internship programs have an impact on the development of professionalism and quality improvement or the quality of graduate students in particular and impact on the development of education in general.

\section{REFERENCES}

Arikunto., 2012. Fundamentals of Educational Evaluation, Second Edition. Jakarta: Earth Literacy .

Arikunto, S., \& Jabar., 2007. Evaluation of Education Program. Revised edition. Jakarta: Earth Literacy.

Chen, T., Shen, C., \& Gosling, M., 2018. Does employability increase with internship satisfaction? Enhanced employability and internship satisfaction in a hospitality program. J. Hosp. Leis. Sport Tour. Educ. 22, 88-99. https://doi.org/10.1016/j.jhlste.2018.04.001.

Dombrowski, R.F., Smith, K.J., \& Wood, B.G., 2013. Bridging the education-practice divide: The Salisbury University auditing internship program. J. Account. Educ. 31, 84-106. https://doi.org/10.1016/j.jaccedu.2012.12.003.

Gajda, R., \& Jennifer J., 2004. Thinking about howto evaluate your program?thesestrategies will get you started. Practical Assessment, Research \&Evaluation, $9(8) . \quad$ Available online: http://PAREonline.net/getvn.asp?v=9\&n=8.

Hamidah, H., Maziah, M., Ayesha, B., Subahan, T., \& Rahayah, A.S., 2012. The Development of a Malaysian Model Internship Programme (MyMIP): A Preceptor Model for Nurses in their Early Stage of Profession. Procedia - Soc. Behav. Sci., 12 th International Educational Technology Conference - IETC 2012 64, 492-500. https://doi.org/10.1016/j.sbspro.2012.11.058.

Kelly, M.A., Hayes, C., \& Abdipranoto, A., 2017. Need a Simulation Technician? Try Your University's Engineering Internship Program. Clin. Simul. Nurs. 13, 245248. https://doi.org/10.1016/j.ecns.2017.02.005.

Khalil, O.E.M., 2015. Students' experiences with the business internship program at Kuwait University. Int. J. Manag. Educ. 13, 202-217. https://doi.org/10.1016/j.ijme.2015.05.003.

Lam, T., \& Ching, L., 2007. An exploratory study of an internship program: The case of Hong Kong students. Int. J. Hosp. Manag., Special Issue on Self-Catering Accommodations 26, 336-351. https://doi.org/10.1016/j.ijhm.2006.01.001.

Nugroho, R., 2009. Public Policy , Jakarta: Elex Media Komputindo.

Peterson., Steven., \& Albert Somit. 2003. Human Nature and Public Policy: An Evolutionary Approach , Palgrave Macmillan.

Scriven, M., 1991. Evaluation Thesaurus 4 th, Newbury Park, CA: Sage Publication. Setiawan., 1999. National Education Agenda. Yogjakarta: Ar-Ruz Media. 
Steward , Jr., Joseph., \& James P. L., 2000. Public Policy: An Evolutionary Approach, 2nd ed., Belmont, CA.

Stufflebeam, D. L., \& Chris. LS. C., 2014. Evaluation Theory, Models, \& Applications , San Francisco: Jossey Bass.

Szafran, R. F., 2007. Assessing Program Outcomes When Participation Is Voluntary: Getting More Out of a Static-Group Comparison. Practical Assessment Research \& Evaluation, 12(8). Available online: http://pareonline.net/getvn.asp?v=12\&n=8.

Tayibnapis, F. Y., 2000. Program Evaluation. Jakarta: Rineka Cipta.

Wirawan. 2011. Evaluation: Theory, Model, Standard, Application, and Profession. Rajawali Press. 